Elsevier Editorial System(tm) for Fish and Shellfish Immunology

Manuscript Draft

Manuscript Number: FSIM-D-07-00013R1

Title: MOLECULAR CLONING, DIFFERENTIAL EXPRESSION AND 3D STRUCTURAL ANALYSIS OF

THE MHC CLASS-II beta CHAIN FROM SEA BASS (Dicentrarchus labrax L.)

Article Type: Full Length Article

Section/Category:

Keywords: major histocompatibility complex class (MHC) II beta chain; sea bass; Dicentrarchus labrax; cloning; polymorphism; expression analysis; quantitative PCR; 3D structure.

Corresponding Author: Dr Francesco Buonocore, PhD

Corresponding Author's Institution: University of Tuscia

First Author: Francesco Buonocore, PhD

Order of Authors: Francesco Buonocore, PhD; Elisa Randelli, PhD; Daniela Casani, PhD student; Susan Costantini; Angelo Facchiano, PhD; Giuseppe Scapigliati, PhD; Renè J Stet

Manuscript Region of Origin:

Abstract: The major histocompatibility complex class I and II molecules (MHC-I and MHC-II) plays a pivotal role in vertebrate immune response to antigenic peptides. In this paper we report the cloning and sequencing of the $\mathrm{MHC}$ class II b chain from sea bass (Dicentrarchus labrax $\mathrm{L}$.). The six obtained cDNA sequences (designated as Dila-DAB) code for 250 amino acids, with a predicted 21 amino acid signal peptide and contain a 28 bp 5'-UTR and a 478 bp 3'-UTR. A multiple alignment of the predicted translation of the Dila-DAB sequences was assembled together with other fish and mammalian sequences and it showed the conservation of most amino acid residues characteristic of the MHC class II b chain structure. The highest basal Dila-DAB expression was found in gills, followed by gut and thymus, lower mRNA levels 
were evidenced in spleen, peripheral blood leucocytes $(\mathrm{PBL})$ and liver. Stimulation of head kidney leukocytes with LPS for $4 \mathrm{~h}$ showed very little difference in the Dila-DAB expression, but after $24 \mathrm{~h}$ the DilaDAB level decreased to a large extent and the difference was statistically significant. Stimulation of head kidney leukocytes with different concentrations of rlL-1b (ranging from 0 to $100 \mathrm{ng} / \mathrm{ml}$ ) resulted in a dosedependent reduction of the Dila-DAB expression. Moreover, two 3D Dila-DAB*0101 homology models were obtained based on crystallographic mouse MHC-II structures complexed with D10 T-cell antigen receptor or human CD4: features and differences between the models were evaluated and discussed. Taken together these results are of interest as MHC-II structure and function, molecular polymorphism and differential gene expression are in correlation with disease resistance to virus and bacteria in teleost fish. 
Dear Prof. Tony Ellis,

I am sending you a revised version of the paper entitled: "MOLECULAR CLONING, DIFFERENTIAL EXPRESSION AND 3D STRUCTURAL ANALYSIS OF THE MHC CLASS-II beta CHAIN FROM SEA BASS (Dicentrarchus labrax L.)" (Ref. n. FSIM-D-07-00013), author team: Francesco Buonocore, Elisa Randelli, Daniela Casani, Susan Costantini, Angelo Facchiano, Giuseppe Scapigliati, Renè J.M. Stet.

I have taken into account most of the suggestions from the referees and I have attached a list of all the changes made in the paper (in the text you will find in bold the phrases that differ form the first version).

I hope that now the paper will be accepted for the publication, but let me know if there is any problem.

Best regards

Dr. Francesco Buonocore 
Dear Prof. Tony Ellis,

I am sending you a revised version of the paper entitled: "MOLECULAR CLONING, DIFFERENTIAL EXPRESSION AND 3D STRUCTURAL ANALYSIS OF THE MHC CLASS-II beta CHAIN FROM SEA BASS (Dicentrarchus labrax L.)" (Ref. n. FSIM-D-07-00013), author team: Francesco Buonocore, Elisa Randelli, Daniela Casani, Susan Costantini, Angelo Facchiano, Giuseppe Scapigliati, Renè J.M. Stet.

I have taken into account most of the suggestions from the referees and I have attached a list of all the changes made in the paper (in the text you will find in bold the phrases that differ form the first version).

I hope that now the paper will be accepted for the publication, but let me know if there is any problem.

Best regards

Dr. Francesco Buonocore

\section{Reviewer \#1:}

This manuscript describes the cloning of 6 cDNA sequences encoding MHC class II beta from sea bass. The sequences have been aligned and analyzed in a phylogenetic tree, the expression of the gene in head kidney leukocytes in response to stimulation with LPS and Il-beta is examined by real time PCR and some homology models have been derived.

\section{General Comments}

This paper is generally well written, although the English need polishing. The data provided are interesting, but much of it is in silico derived from the sequences and the addition of a few more "wet lab" experiments would greatly enhance the story the authors are trying to tell. For example, sequencing cDNAs does not really give gene copy number or even number of expressed genes due to primer bias/fit among other problems. The addition of a Southern blot, an analysis of the expression levels in different tissues or the examination of the real degree of polymorphism by sequencing the putative PBR regions from several other individuals (up to 50 sequences) would provide more evidence that these are the functional genes of Sea Bass and enhance the publish ability of this manuscript.

I have added an analysis of the MHC expression levels in different tissues. The Southern blot has not been added as an attempt to evidence the number of class II $B$ loci in sea bass is already present in the paper (see the beginning of "Results" section). The examination of the real degree of polymorphism was not in the aim of the authors, but the idea was to focus on the analysis of functional evidences rela ted to the MHC gene.

The discussion is very weak and fails to discuss important questions such as why the expression of genes that are key to the immune response is down-regulated after stimulation - th is seems to mean that the immune response is being shut down. The rest of the discussion needs more explanation of the data rather than simply saying it agrees or disagrees with the literature.

I have improved the Discussion taking into account the reviewer suggestions. 
Specific comments:

line 63: Redundant language

I have changed the phrase.

line 65: in terms of linkage? Polymorphism? Classical/non-classical? Clarify

I have clarified the sentence.

line 229 "they encode"

I have corrected the mistake.

line $244 ; 11 \%$ identity - no "of"

I have corrected the mis take.

line 257 ; The trout glycosylation site is more than just "potential" the protein is definitely glycosylated - see: Immunogenetics (2006) 58: 443-453

"Potential" was referred to sea bass and not to the other species, I have added the reference.

Line 258: Figure 2 - why were amino acid sequences used? DNA has more usable data and avoid convergence more. Why are some names capitalized and others not?

Yes, usually DNA has more usable data and avoid convergence more, but we got similar results with DNA or amino acid, so we decide to use the latter as it was more straightforward after the alignment. I have used only capitalized names in the tree.

Line 265, figure 3 Did you measure IL-1b expression after LPS stimulation to ensure you actually got stimulation? (oh I see you did at line 392-394 - you should mention this earlier). Sometimes LPS doesn't work so well on fish, especially from E coli. This concentration seems very low - other papers have used as much as $100 \mathrm{ug} / \mathrm{ml}$. Why was this concentration chosen - was a preliminary experiment using a range of concentrations done to as sess how much is needed to elicit a response? Why did the expt only go to 24 hours? It seems that MHC expression should be affected for a long time after that.

I have added a phrase in the "Results" section related to the studying of IL-1 $\beta$ expression to ensure LPS stimulation. The LPS concentration worked well in a lot of dif ferent experiments we performed in the past (for a reference see: G. Scapigliati, F. Buonocore, S. Bird, J. Zou, P. Pelegrin, C. Falasca, D. Prugnoli and C.J. Secombes. Phylogeny of cytokines: molecular cloning and expression analysis of sea bass Dicentrarchus labrax interleukin-1 $\beta$. Fish and Shellfish Immunology (2001), 11(8):711-726; F. Buonocore, E. Randelli, D. Casani, M. Mazzini, I. Cappuccio, C.J. Secombes, G. Scapig liati. cDNA cloning and expression a nalysis of a cyclooxygenase-2 from sea bass (Dicentrarchus labrax L.) after vaccination. Aquaculture (2005), 245(1-4): 301-310; F. Buonocore, M. Forlenza, E. Randelli, S. Benedetti, P. Bossù, S. Meloni, C.J. Secombes, M. Mazzini, G. Scapigliati Biological activity of sea bass (Dicentrarchus labrax) recombinant interleukin-1 $\beta$. Marine Biotechnology (2005), 7(6): 609617), so we used the same. We did not look at the MHC expression after $24 \mathrm{~h}$ both because LPS elic it inflammatory responses quickly (few hours post-stimulation) and as the viability of 
fish leukocyte cultured cells is quite low, so to study the MHC expression for a long time we should perform "in vivo" experiments.

Line 290 is $34 \%$ identity enough to do this?

Yes, it is enough with the used computational methods (for a reference see: Facchiano AM, Stiuso P, Chiusano ML, Caraglia M, Giuberti G, Marra M, et al. Homology modelling of the human eukaryotic initiation factor 5A (eIF-5A). Protein Engineering 2001; 14: 881-90; Marabotti A, D'Auria S, Rossi M, Facchiano AM. Theoretical model of the three-dimensional structure of a sugar binding protein from Pyrococcus horikoshii: structural analysis and sugar binding simulations. Biochem $J$ 2004; 280:677-84). I have added a phrase in the "Results" section.

Line 369-370: there is variability - you can't say it is "high" based on 6 sequences

I have changed the phrase.

Lines 393-403: but why does MHC expression go down - this is decreasing the immune response in response to a simulated infection - isn't this bad?? You need to discuss the implications of this?

Does the MHC expression increase later?????

MHC down-regulation in our samples could be very likely linked to the already reported mechanisms for the control of inflammation responses in mammals that, uncontrolled, may have dangerous effects. For example, during early inflammation, various cytokines are produced and they down-regulate the expression of in flammation-related molecules.

\section{Reviewer \#2}

\section{General comments:}

The manuscript outlines the isolation and structural analysis of six full length MHC class II B sequences cDNA sequences in Sea Bass, a topic which should be of relevance and interest to the readership of Fish and Shellfish Immunology. While I can't speak authoritatively about the structural analysis, the science appears sound and the methods clear. There are a few instances where the English word ing could use improvement (see below), but generally the manuscript is well organised and written.

I would have liked further elaboration about the potential impact of the modeling exercise on our und erstanding of the function of this gene.

I have improved the Discussion taking into account the reviewer suggestions.

Given that the two models differed in perhaps the most important site-the ligand binding region, how can one differentiate which is correct?

The two models represent two conformations of the same protein under different conditions, i.e. the interaction with two different ligands, and this may explain why the main structural differences involve the binding sites, as observed by the referee. It is not possible to indicate if one model is better than the other. Each model predicts the structural organization of the protein when it in teracts with CD4 or TCR, so both models can be useful for further experimental studies to simulate the interaction with the respective ligand and confirm the structural prediction. 
How does the size of the binding site relate to the size of the potential ligand?

The binding sites for the antigen peptide and CD4 resulted larger in the MHC conformation which interacts with these ligands, and the binding site for TCR resulted larger in the MHC conformation which interacts with TCR. We wrote that th is observation confirms the reliability of the two models. In fact, this results is in agreement with the ability of any protein to adopt a conformation more suitable to the interaction. The larger surface implies a better ability to in teract with the ligand. As an example, it is well known that enzymes expose better the catalytic site in the presence of the substrate. Therefore, the measures of the surfaces for the binding sites confirm that our models are suitable to simulate the different conformations of MHC when it interacts with the two different ligands.

The authors should consider revising their final concluding sentence, as it is too long and cumbersome. As a note, they have not demonstrated that the genes they identified are actually maintain ed by pathogen-driven selection.

The final sentence has been revised.

English could be better in places, some of which are outlined below:

Line 194: significativity -- what is that? Should be signific ance

I have changed the word.

Line 232: in order to verify the number of class II B locus (should be loci)

I have changed the word.

Line 233: perfomed should be performed

I have changed the word.

Line 239: seems to express up to three class II b loci at least (up to and at least are contradictory terms. Should read at least three class IIb loci)

I have changed the phrase.

Line 325: where the strands include less amino acids (should read fewer amino acids)

I have changed the word.

Line 361: growing evidences suggest should read growing evidence suggests

I have changed the phrase.

Line 397: I am not sure what is meant by similar results... after infection with IHNV on MHC class I-what? That expression of class I or class II was downregulated?

I have changed the phrase.

Line 404: the identity percentage should read percentage identity 
I have changed the phrase. 


\section{Figure 1}

signal peptide

beta-1

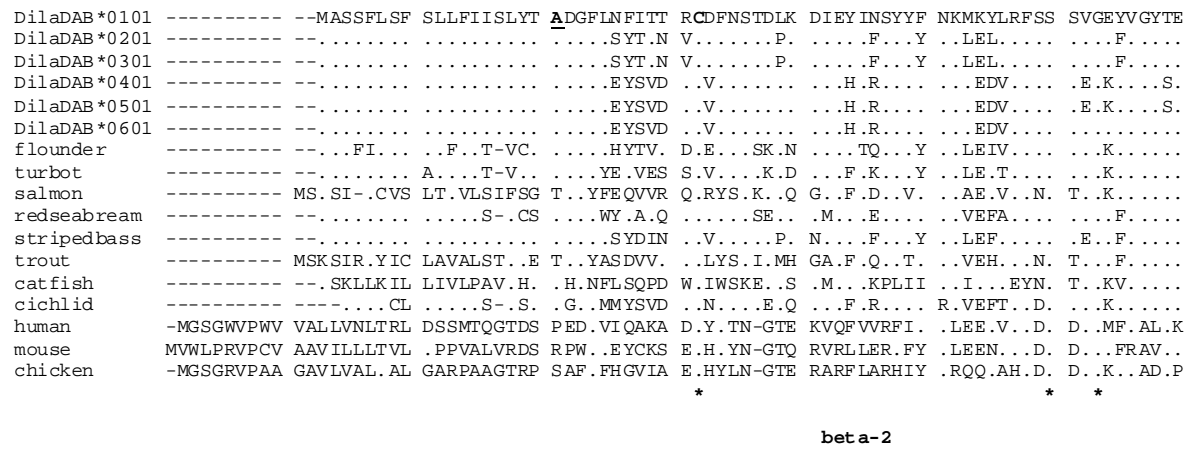

DilaDAB*0101 LGVKNAERLN KDP SELARRR GEKERYCLTN VNADYQGALD KSVKRPYVVLH SVAP PAGKHP SMLVCSVYGF YPKHIRVSWL

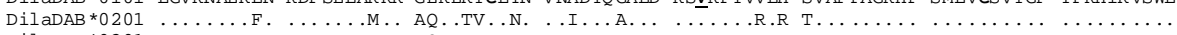

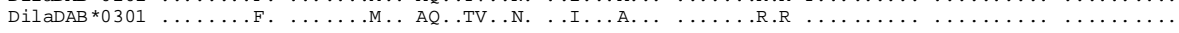

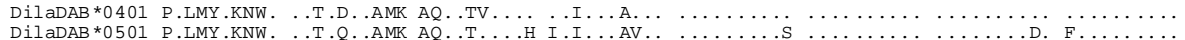

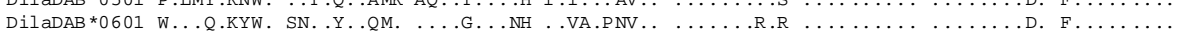

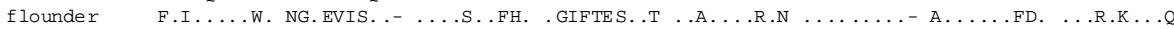

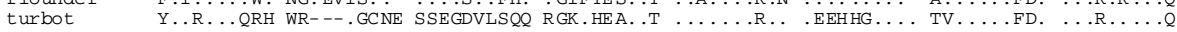

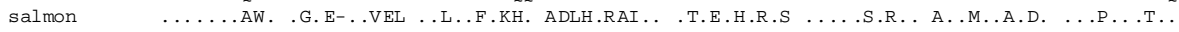

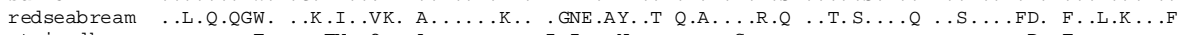

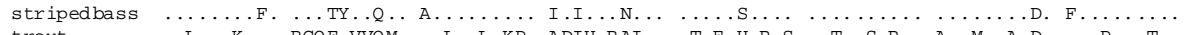

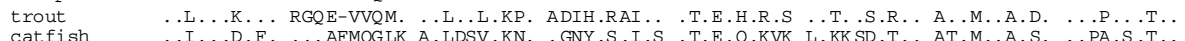
cichlid

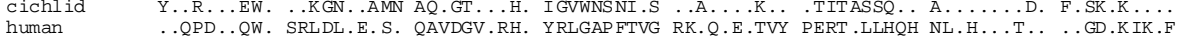
mouse $\quad$.RPD...NW. SQ.EF.EQK. A.VDTV.RH. YEISDKFLVR RR.E.T.TVY PTKTQPLE.H NL.....SD. ..GN.E.R.F

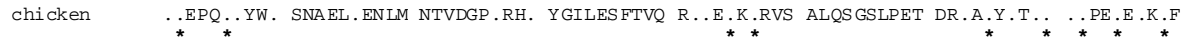

connecting transmembrane
peptide

DilaDAB*0101 RDGQEVTSDV TSTDELADAD WFYQIHSHLE Y TPRSGEKIS CVVEHASLRE PLVT DWDPSM PESERNKIAI GASGLI LGLI

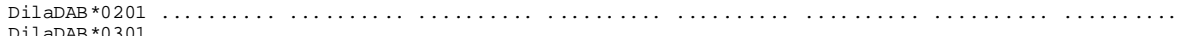

DilaDAB *0301

Dil $a \mathrm{DAB} * 0401$

Dil $a \mathrm{DAB} * 0501$

flounder

turbot

salmon

redseabream

stripedbass

trout

catfish

cichlid

human

chicken

‥

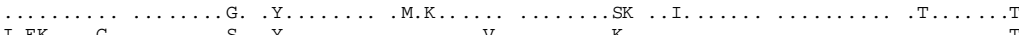

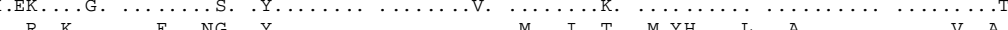

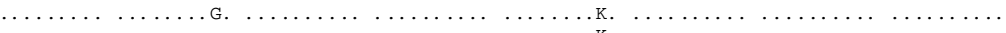

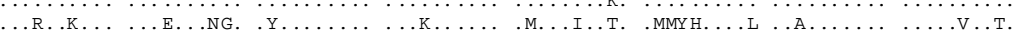

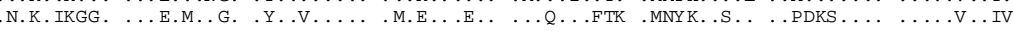

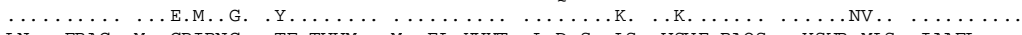
G. M..GPIRNG. .TF.TVVM.. M..EL. HVYT .I.D.S ..LS .VSVE.RAQS -.YSWR.MLS .IAAFL $\ldots$

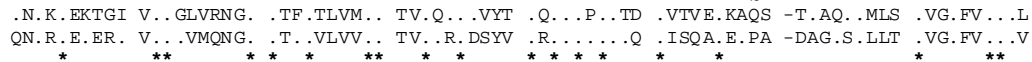

cytoplasmic

tail

DilaDAB*0101 LSLAGFIY $\underline{\mathbf{Y} K}$ RKA RGRILVP SN------- -----

Dil $a \mathrm{DAB} * 0201$

Dil $a \mathrm{DAB} * 0301$

Dil $a \mathrm{DAB} * 0401$
Dil $\mathrm{aDAB} * 0501$

DilaDAB*0601

flounder

turbot

salmon

redseabream

stripedbass

trout

catfish

cichlid

human

mouse
chicken

A. .

A. . L.... K.SS.VL- .

...... т....... .

$\begin{array}{lllll}\ldots \ldots & \ldots \ldots & \ldots\end{array}$

........ K.SS..... T------- ----

FL.V. IVIQL . AQK. YVR TQ MSGNEVSRAV LIPQSC FLG. .LFI.F . NQK. QSGLQ PTG------- LLS--

FLAL. LFVFL .GQK. . PVAA APG------- MLN--- 
Figure 2

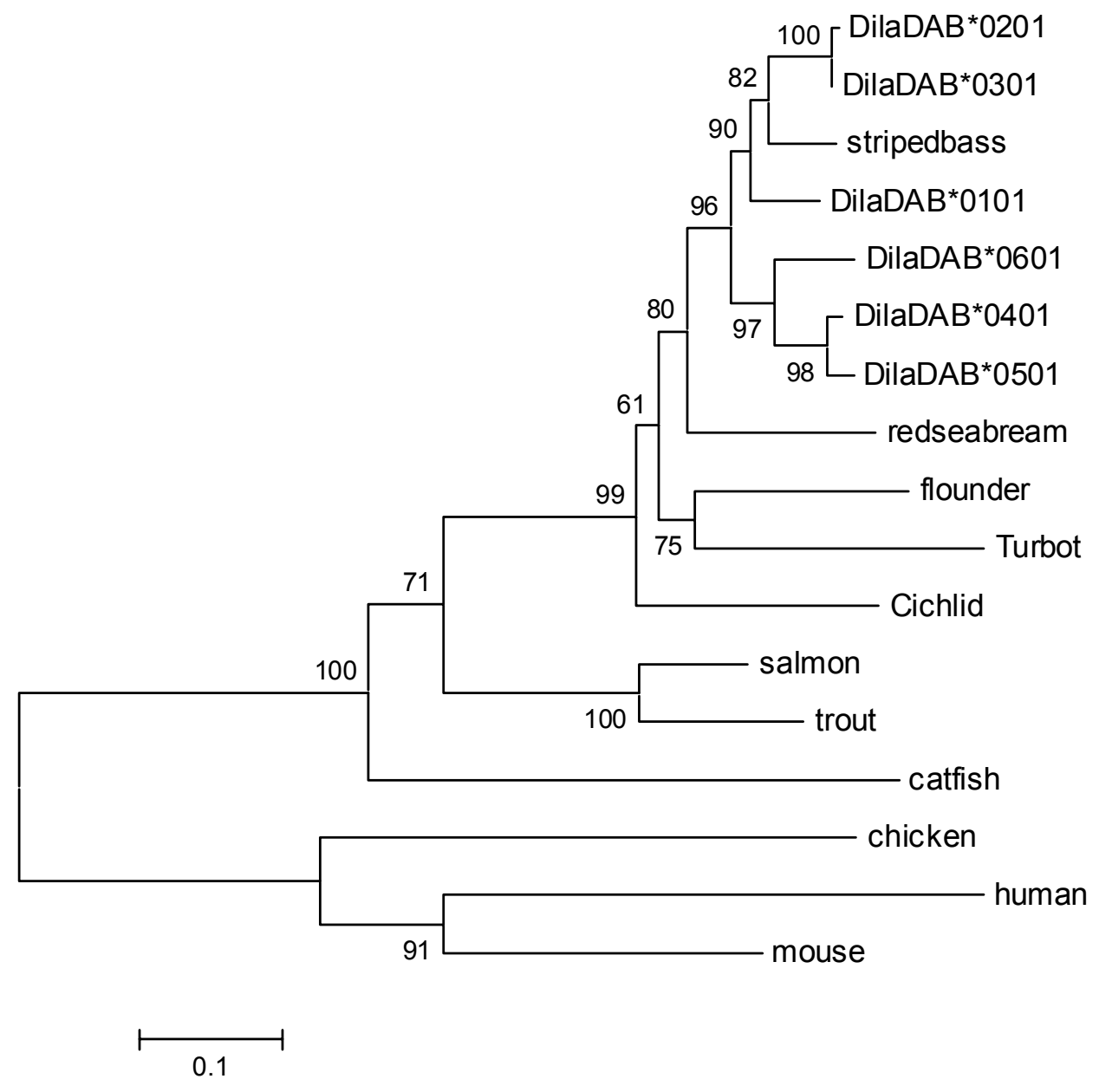


Figure 3

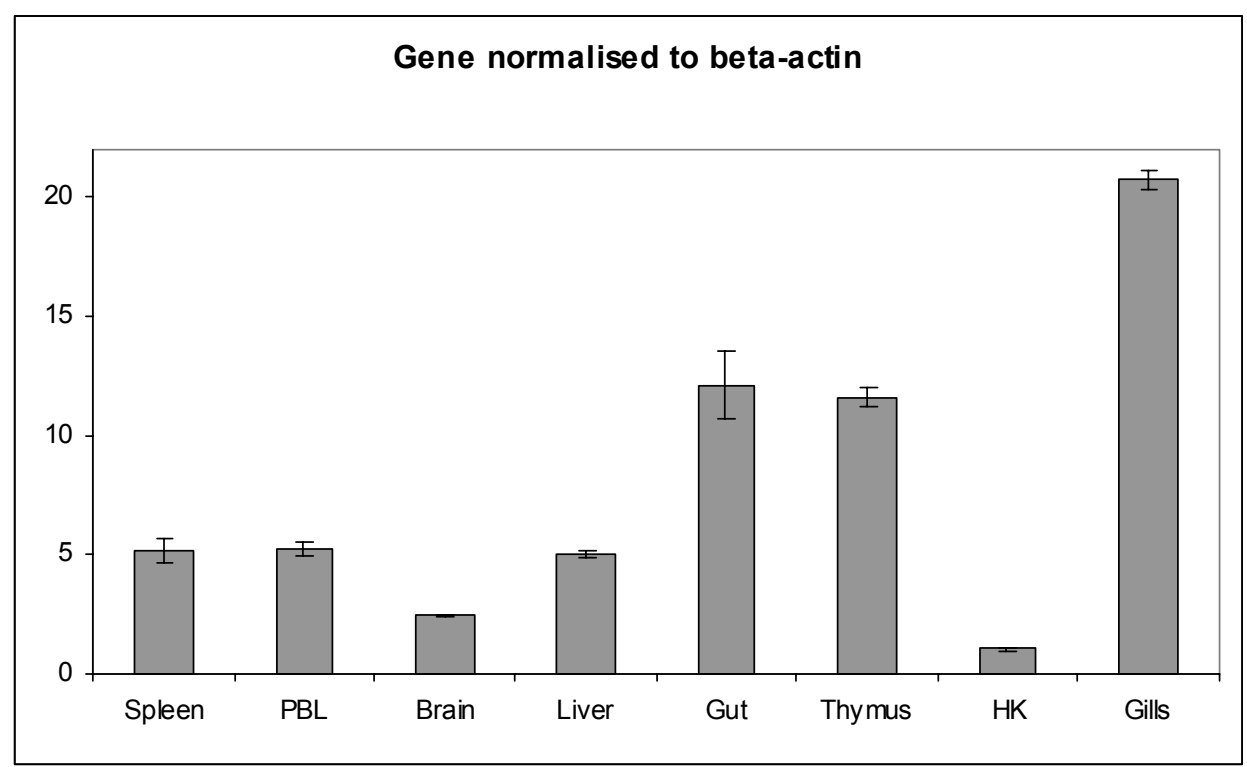



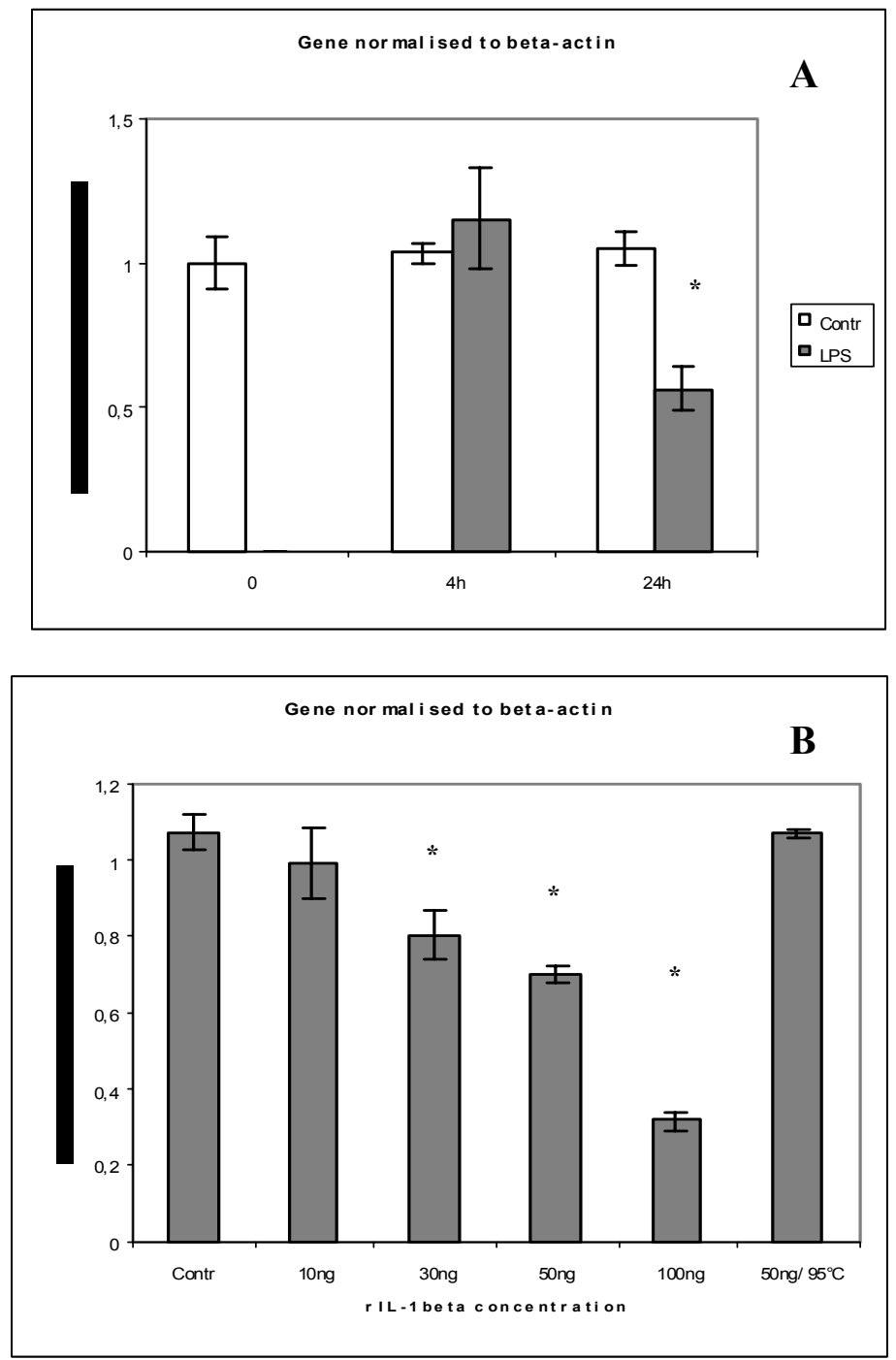


\section{Figure 5}

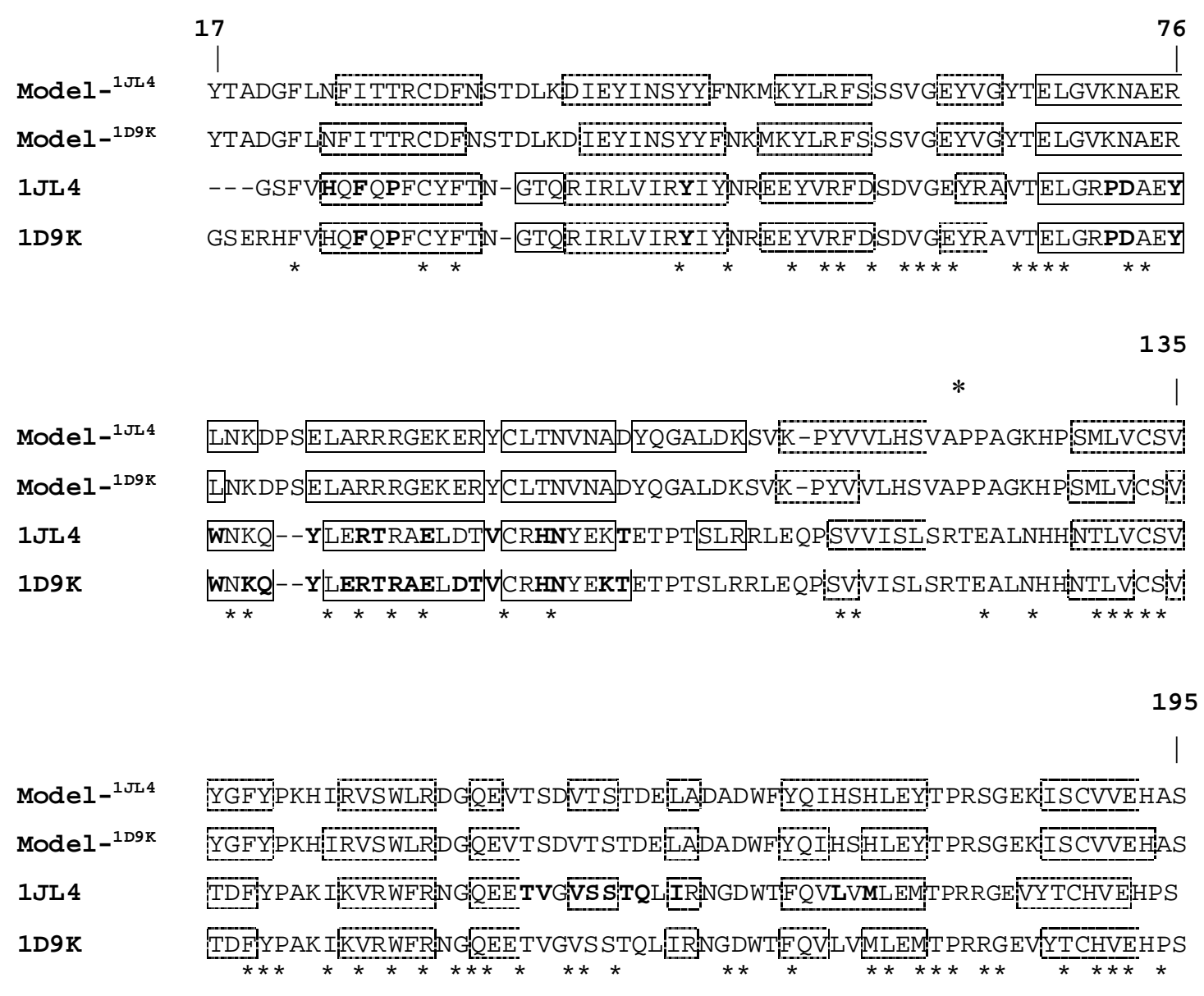

206

Model-1ज4 LREPLVTDWPP

Model-1D9K LREPLVTDWDP

1 JL4 LTSPITVEWRA

1D9K LTSPITVEjWRA 
Figure(s)

Figure 6
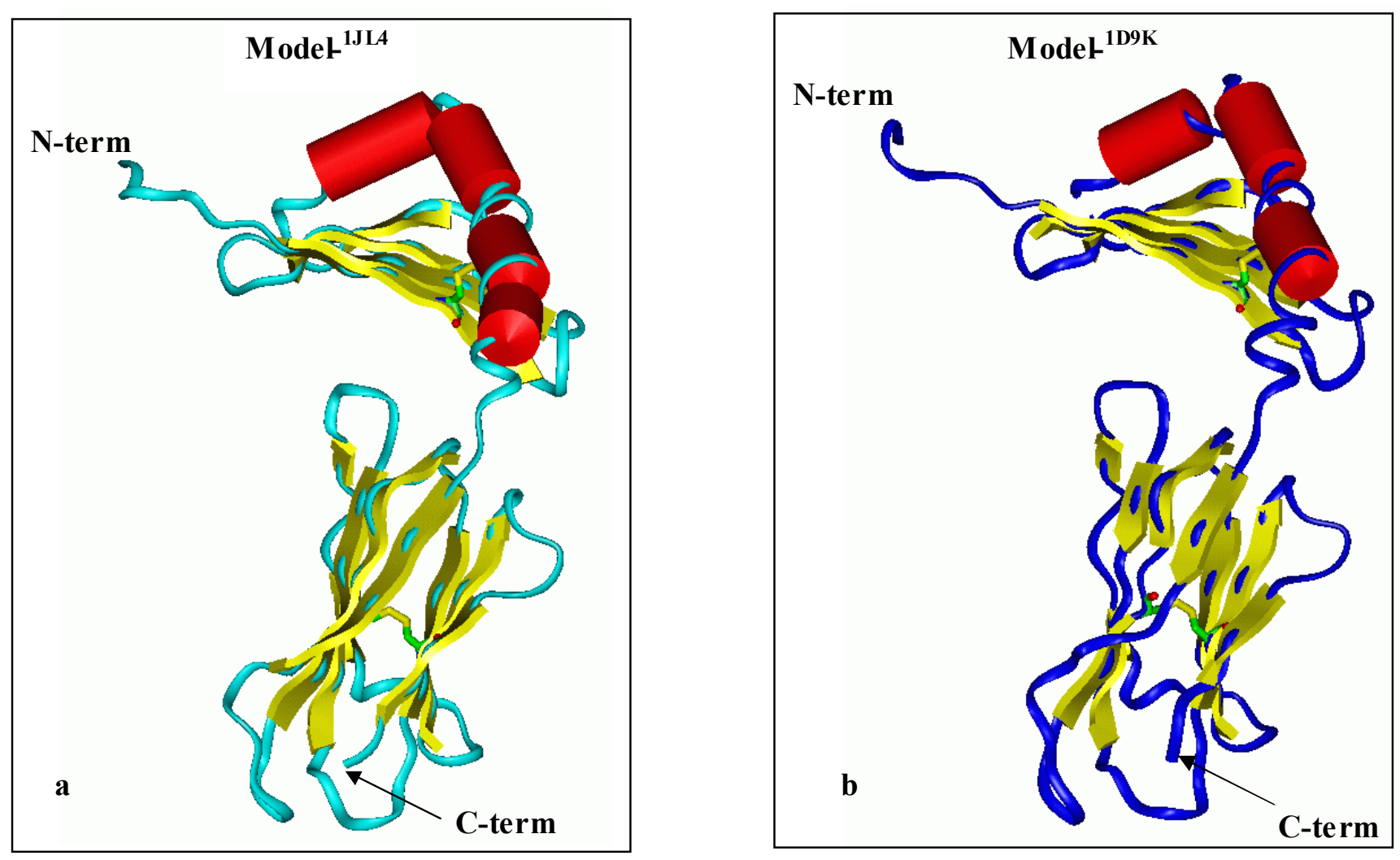
2

3

4

5

6 9 Italy

10

11

12

13

14

15

16

17

18

19

20

21

22

23

24

\section{BASS (Dicentrarchus labrax L.)}

\section{Francesco Buonocore*, Elisa Randelli, Daniela Casani, Susan Costantini ${ }^{2}$,} Angelo Facchiano², Giuseppe Scapigliati, Renè J.M. Stet ${ }^{1}$

Dipartimento di Scienze Ambientali, University of Tuscia, Largo dell’Università, 01100 Viterbo,

${ }^{1}$ Scottish Fish Immunology Research Centre, University of Aberdeen, Tillydrone Avenue, AB24

2TZ Aberdeen, Scotland, UK.

${ }^{2} \mathrm{CNR}$, Istituto di Scienze dell'Alimentazione, I-83100 Avellino, Italy

*Corresponding author: Dr. Francesco Buonocore, Dipartimento di Scienze Ambientali, Università della Tuscia, Largo dell’Università s.n.c., I-01100 Viterbo, Italy.

Phone +39-0761-357644; Fax +39-0761-357179; Email: fbuono@unitus.it 
The major histocompatibility complex class I and II molecules (MHC-I and MHC-II) plays a

pivotal role in vertebrate immune response to antigenic peptides. In this paper we report the cloning and sequencing of the MHC class II $\beta$ chain from sea bass (Dicentrarchus labrax L.). The six obtained cDNA sequences (designated as Dila-DAB) code for 250 amino acids, with a predicted 21 amino acid signal peptide and contain a 28 bp 5'-UTR and a 478 bp 3'-UTR. A multiple alignment of the predicted translation of the Dila-DAB sequences was assembled together with other fish and mammalian sequences and it showed the conservation of most amino acid residues characteristic of the MHC class II $\beta$ chain structure. The highest basal Dila-DAB expression was found in gills, followed by gut and thymus, bwer mRNA levels were found in spleen, peripheral blood leucocytes (PBL) and liver. Stimulation of head kidney leukocytes with LPS for 4 h showed very little difference in the Dila-DAB expression, but after $24 \mathrm{~h}$ the Dila-DAB level decreased to a large extent and the difference was statistically significant. Stimulation of head kidney leukocytes with different concentrations of rIL-1 (ranging from 0 to $100 \mathrm{ng} / \mathrm{ml}$ ) resulted in a dose-dependent reduction of the Dila-DAB expression. Moreover, two 3D Dila-DAB*0101 homology models were obtained based on crystallographic mouse MHC-II structures complexed with D10 T-cell antigen receptor or human CD4: features and differences between the models were evaluated and discussed. Taken together these results are of interest as MHC-II structure and function, molecular polymorphism and differential gene expression are in correlation with disease resistance to virus and bacteria in teleost fish.

Keywords: major histocompatibility complex class (MHC) II $\beta$ chain; sea bass; Dicentrarchus labrax; cloning; polymorphism; expression analysis; quantitative PCR; 3D structure. 
The major histocompatibility complex class I and II molecules (MHC-I and MHC-II) are

51 fundamental components of the immune response to foreign protein antigens. They have been

extensively studied in mammals, especially in humans [1], mouse and rat. The MHC molecules are heterodimers formed by $\alpha$ and $\beta$ membrane glycoproteins that bind self and non-self peptides for presentation on the cell surface to T-cells. MHC-II binds peptides for presentation to the $\mathrm{CD} 4^{+} \mathrm{T}$ helper cells [2-3] and it is encoded by two genes, $A$ and $B$ [4], in mammals. MHC-II genes are constitutively expressed in antigen-presenting cells such as macrophages, B cells, monocytes and dendritic cells. They are highly polymorphic with multiple loci and alleles and this polymorphism gives the possibility to bind a large number of peptide ligands. Crystal structures of different MHC II proteins in mammals have shown that bound peptides are deeply integrated into the MHC structure using two main classes of interactions: 1) conserved hydrogen bonds to the peptide backbone; 2) at least four prominent pockets that accept peptide side chains [5-7].

In teleosts, MHC class I and II genes have been identified in various species and it has been established that class I and II loci reside in different linkage groups [8]. Fish MHC class II molecules are comprised of $\alpha$ and $\beta$ subunits, like in mammals, and class II $\boldsymbol{B}$ loci are in separate linkage groups in all Euteleostei [9]. MHC class II genes have been isolated from numerous fish species such as striped sea bass (Morone saxatilis) [10], red sea bream (Chrysophrys major) [11], various cichlids [12], salmonids [13-15] and different cyprinids [16-20].

MHC II genes in teleosts are also polymorphic and various studies have tried to establish the association of the MHC diversity [21-22] or differential gene expression [22-27] with disease resistance to virus and bacteria, as such associations were identified in humans [28] and chicken [29].

In this study we report the cloning and sequencing of the MHC class II $\beta$ chain from sea bass (Dicentrarchus labrax L.), one of the most important species in aquaculture in the South Mediterranean, and studied its basal expression levels and under different "in vitro" conditions by 
75 real-time PCR. These results will add a new tool for studying the effects of vaccination and 76 immuno-stimulation on the sea bass immune system. Moreover, we predicted, for the first time, the 77 3D structure of a MHC class II $\beta$ chain from a teleost fish by homology modelling, a starting point 78 for successive structural-functional investigations on this fundamental immune molecule.

79

80

81

82

83

84

85

86

87

88

89

90

91

92

93

94

95

96

97

98

99

100

101

102

103

104

105

106

107

108

109

110

111

112

113

114

115 


\section{MATERIALS AND METHODS}

117

118

\subsection{Sea bass MHC class II $\beta$ chain cloning and sequencing}

Two degenerate primers (MHCFR1 5'- TGCWGYGYRTAYGRSTTCTACCC - 3' and MHCRV1 5' AGGCTKGKRTGCTCCACCWRRCA -3' where $\mathrm{Y}=\mathrm{C} / \mathrm{T}, \mathrm{K}=\mathrm{G} / \mathrm{T}, \mathrm{R}=\mathrm{G} / \mathrm{A}, \mathrm{S}=$ $\mathrm{G} / \mathrm{C}, \mathrm{W}=\mathrm{A} / \mathrm{T}$ ) corresponding to highly conserved regions of known MHC class II $\beta$ genes [30] were used for RT-PCR on to tal RNA extracted with Tripure (Roche) solution from one juvenile sea bass (150 g of weight) head kidney. The leukocyte head kidney cells were obtained after Percoll purification as a single fraction following the procedures described in [31]. RT-PCR was performed using Ready-To-Go RT-PCR Beads (Amersham Pharmacia). For cDNA synthesis, $1 \mu \mathrm{g}$ of total RNA and $0.5 \mu \mathrm{g}$ of random primers $\left[\mathrm{pd}(\mathrm{N})_{6}\right]$ were used in each reverse transcription reaction in a total volume of $50 \mu 1$. Reactions were conducted using the Mastercycler personal (Eppendorf). The cycling protocol was one cycle of $94^{\circ} \mathrm{C}$ for $5 \mathrm{~min}, 35$ cycles of $94^{\circ} \mathrm{C}$ for $45 \mathrm{~s}, 60^{\circ} \mathrm{C}$ for $45 \mathrm{~s}, 72^{\circ} \mathrm{C}$ for $45 \mathrm{~s}$, followed by one cycle of $72{ }^{\circ} \mathrm{C}$ for $10 \mathrm{~min}$. PCR products $(15 \mu \mathrm{l})$ were visualised on $1 \%$ (w/v) agarose gels containing ethidium bromide $(10 \mathrm{ng} / \mathrm{ml})$ using hyperladder IV (Bioline) as size marker. Controls for the presence of DNA contamination were performed using the RNA samples as template. DNA amplified by PCR was purified using the QIAquick Gel Extraction Kit (QIAgen), inserted into the pGEM-T Easy vector (Promega) and transfected into competent JM109 Escherichia coli cells. Plasmid DNA from at least ten independent clones was purified using the Wizard Plus SV Minipreps DNA Purification System (Promega) and sequenced using MWG DNA Sequencing Services. Sequences generated were analysed for similarity with other known MHC class II $\beta$ sequences using the FASTA [32] and BLAST [33] programs and multiple alignments were made with MEGA 3.1 Software [34].

Further primers were designed based on the initial sea bass MHC class II $\beta$ sequences for 5'and 3'- rapid amplification of cDNA ends (RACE)-PCR (MHC-F1 5'TCAGAGTGAGCTGGCTCAGA-3' and MHC-F2 5'-GGTCTGGAGAGAAGATCTCC-3'; MHC- 
1423 '). cDNA was synthesised from the same total head kidney RNA with the First-strand cDNA

143 Synthesis kit (Amersham Pharmacia) following the manufacturers instructions. For 3' RACE-PCR,

144 cDNA was transcribed from the same total head kidney RNA using an oligo-dT adaptor primer (5'-

145 CTCGAGATCGATGCGGCCGCT $15^{-3}$ '). PCR was performed initially with the MHC-F1 primer

146 and the oligo-dT adaptor primer, followed by a semi-nested PCR using MHC-F2 primer and the 147 adaptor primer (5'-CTCGAGATCGATGCGGCCGC-3'). For 5' RACE-PCR, cDNA was 148 transcribed from total RNA using the oligo-dT primer, treated with E. coli RNase H (Promega), 149 purified using a PCR Purification Kit (QIAgen), and tailed with poly(C) at the 5' end with terminal 150 deoxynucleotidyl transferase (TdT, Promega). PCR was performed initially with MHC-R1 primer 151 and an Oligo-dG primer (5'-GGGGGGIGGGIIGGGIIG-3'), and then semi-nested with MHC-R2 152 and the oligo-dG primers. Sequencing and similarity searches were as described above.

153 The obtained cDNA sequences were analysed for the presence of a signal peptide, using SignalP 154 software [35], and of N- (with the NetNGlyc 1.0 Server) and O-linked glycosylation sites [36]. 155 Comparison of the sea bass MHC class II $\beta$ amino acid sequences to their counterparts from other 156 fish and mammalian species was carried out using the DIALIGN program [37]. A phylogenetic tree 157 was constructed by the "neighbour-joining" method using MEGA 3.1 Software [34] on full-length 158 amino acid sequences and bootstrap values calculated.

\subsection{Basal MHC class II $\beta$ chain expression}

To study the IL-10 basal expression, 5 sea bass juveniles (150 $\mathrm{g}$ of weight) were sa mpled and leucocytes from different tissues and organs [spleen, peripheral blood leukocytes (PBL), bra in, liver, gut, thymus, head kidney (HK), gills] obtained as described in [31].

BioScript RNase $\mathrm{H}$ minus (Bioline) enzyme was used with the following protocol: $2 \mu \mathrm{g}$ of total

165 RNA was mixed with $1 \mu \mathrm{l}$ of random hexamer $(0.2 \mu \mathrm{g} / \mu \mathrm{l}$; Amersham Pharmacia) and nuclease 
min and then cooled on ice. Successively, $0.4 \mu \mathrm{l}$ of a reaction mix containing $100 \mathrm{mM}$ dNTPs (25mM each; Promega), $4 \mu \mathrm{l}$ of $5 \mathrm{X}$ Reaction buffer, nuclease free water to a final volume of $19.75 \mu$ land $0.25 \mu l$ of BioScript at $200 \mathrm{u} / \mu \mathrm{l}$ were added and the solution incubated first at 25 ${ }^{\circ} \mathrm{C}$ for $10 \mathrm{~min}$ and than at $37^{\circ} \mathrm{C}$ for $60 \mathrm{~min}$. Finally, the reaction was stopped by heating at 70 ${ }^{\circ} \mathrm{C}$ for $10 \mathrm{~min}$.

The expression le vel of MHC class II $\beta$ chain was determined with a $\mathrm{Mx3000P}^{\mathrm{TM}}$ real time PCR system (Stratagene) equipped with version 2.02 software and using the Brilliant SYBR Green Q-PCR Master Mix (Stratagene) following manufacturer's instructions, with ROX as internal reference dye. Specific PCR primers were designed for the amplification of abo ut 200 bp products from both MHC class II $\beta$ chain and $\beta$-actin (used as housekeeping gene) transcripts. The primers were: RTMHCFR 5'-CAGAGACGGACAGGAAG-3' and respectively. Approximately $50 \mathrm{ng}$ of cDNA template was used in each PCR reaction. The

181 PCR cycle conditions were $95{ }^{\circ} \mathrm{C}$ for $10 \mathrm{~min}$, followed by 35 cycles of $95{ }^{\circ} \mathrm{C}$ for $45 \mathrm{~s}, 52{ }^{\circ} \mathrm{C}$ for $45 \mathrm{~s}$ and $72{ }^{\circ} \mathrm{C}$ for $45 \mathrm{~s}$. Triplicate reactions were performed for each template cDNA and the template was replaced with water in all blank control reactions. Each run was terminated with a melting curve analysis (all points method) which resulted in a melting peak profile specific for the amplified target DNA and the PCR products were examined by agarose gel electrophoresis. Fluorescence data were collected during the extension stage of amplification. Analysis of the data was carried out using the endpoints method option of the Mx3000P ${ }^{\mathrm{TM}}$ software.

190 cha in expression was used as calibrator and the $\boldsymbol{\beta}$-actin as the normaliser. 
The "in vitro" expression of MHC class II $\beta$ chain was studied by stimulating leukocytes

193 isolated by Percoll gradients [31] from the head kidney of 5 sea bass juveniles ( $150 \mathrm{~g}$ of weight).

194 In one stimulation, the head kidney leucocytes from the single fishes after Percoll purification,

195 were adjusted to $1 \mathrm{X} 10^{5}$ cells $/ \mathrm{ml}$ and incubated at $18{ }^{\circ} \mathrm{C}$ for $4 \mathrm{~h}$ and $24 \mathrm{~h}$ with $5 \mu \mathrm{g} / \mathrm{ml} \mathrm{of}$

196 lipopolysaccharide (LPS from E. coli 0127:B8, Sigma).

197 In another stimulation, the head kidney leucocytes from the single fishes after Percoll 198 purification, were adjusted to $1 \times 10^{5}$ cells $/ \mathrm{ml}$ and incubated at $18{ }^{\circ} \mathrm{C}$ for $24 \mathrm{~h}$ in the presence of 10 ,

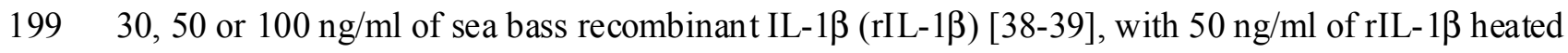
200 at $95{ }^{\circ} \mathrm{C}$ for 20 min or with no recombinant protein, in $5 \mathrm{ml}$ of $\mathrm{L} 15$ medium (Gibco).

201 Total RNA was extracted from experimental cultures after the stimulations with Tripure 202 (Roche) and real-time PCR conditions were as described above for the basal expression.

Data were expressed as the mean $\pm \mathrm{SE}$ and the differences from the control at the same time have been considered significant if $\mathrm{p}<0.05$ using the standard student $t$ test to analyse the significance.

\subsection{Sea bass MHC class II $\beta$ chain protein modelling}

Three-dimensional models of sea bass MHC class II $\beta$ chain were created following the homology modelling procedure described in previous papers [40-44], also in agreement with the rules recently reviewed [45] to improve the quality of the modelling results. The BLAST program

210 [33] was used to find homologous proteins in databases. Structure predictions of sea bass MHC 211 class II $\beta$ chain were based on the availability of the three-dimensional models of the homologous 212 mouse MHC I-A ${ }^{\mathrm{K}}$ chain $\beta$ protein complexed with antigen peptide and D10 T-cell antigen receptor 213 [46] (PDB code: 1D9K) and with antigen peptide and human CD4 [47] (PDB code: 1JL4). The 214 alignment of the protein sequences was made with CLUSTALW program [48] and a few manual 215 refinements were added to account for the position of secondary structures. Full-atom models of sea 216 bass MHC were created with the MODELLER module [49] of Quanta (Accelrys, Inc., San Diego, 
217 CA, USA) by using as template each of two crystallographic structures, by setting 4.0 Angstroms as

218 RMS deviation among initial models and by full optimization of models, i.e. multiple cycles of 219 refining with conjugate gradients minimization and molecular dynamics with simulated annealing. 220 The best models were chosen by evaluating their stereochemical quality with the PROCHECK 221 program [50] and a scoring function with ProsaII program [51]. Secondary structures were assigned 222 by the DSSP program [52]. Search for structural classification was performed on CATH database 223 [53]. The "Protein-Protein Interaction Server" (http://www.biochem.ucl.ac.uk/bsm/PP/server) [54] 224 and the program NACCESS [55] were used to identify the amino acids at the protein-protein 225 interface in the crystallographic complexes. Molecular superimposition, RMSD values and figures 226 were obtained with the In sightII package (Accelrys, Inc., San Diego, CA, USA).

227

228

229

230

231

232

233

234

235

236

237

238

239

240

241

242

243

244

245

246

247

248

249

250

251

252

253

254

255

256

257 


\section{RESULTS}

\subsection{Sea bass MHC class II $\beta$ chain cloning and sequencing}

PCR with primers MHCFR1 and MHCRV1 resulted in products of the expected size (190 bp) with similarity to other known MHC class II $\beta$ sequences (data not shown). 3'-RACE-PCR performed with MHC-F2 (based on the initial $190 \mathrm{bp}$ sequence) and the adaptor primer to extend the sea bass MHC sequence gave a product of about $690 \mathrm{bp}$ that contained the 3 '-end of the gene. 5'-RACE-PCR was then performed with MHC-R2 (based on the initial $190 \mathrm{bp}$ sequence) and oligo$\mathrm{dG}$, and gave a product of about $460 \mathrm{bp}$ that contain ed the 5 '-end of the gene, with some differences between the selected clones. The six full-length nucleotide sequences (EMBL accession numbers $\underline{\text { AM113466 }}, \underline{\text { AM113467 }}, \underline{\text { AM113468 }}, \underline{\text { AM113469 }}, \underline{\text { AM113470 }}, \underline{\text { AM113471) }}$ are comprised of 1259 and have been designated as Dila-DAB sequences (from *0101 to *0601). They encode for 250 amino acids, with a predicted 21 amino acid signal peptide, and a 28 bp 5'-UTR and a 478 bp 3'UTR (Fig. 1). The 3'-UTR contained a polyadenylation signal (AATAAA) 12 bp upstream of the $\operatorname{poly}(\mathrm{A})$ tail.

In order to verify the number of class II $B$ loci, PCR of the open reading frame was performed on the cDNA used for the MHC class II $\beta$ chain cloning with specific primers (MHCTOTFR 5'GGCTTCATCCTTTCTCAG-3' and MHCTOTRV 5'-TACTGGGAACCAGAATCC-3') and 10 clones were sequenced, confirming the presence of the six different sequences already obtained with the superimposition of the fragments coming from 3' and 5' RACE. In addition, 10 clones of the 3' UTR sequences from the same individual were sequenced and three different sequences were identified, which should demonstrate that sea bass seems to express at least three class II $\boldsymbol{B}$ loci.

A multiple alignment of the predicted tran slation of Dila-DAB sequences was assembled (Fig. 1) together with some fish, mammalian and avian species to investigate the conservation of characteristic amino acid residues. The $\beta-1$ domain comprises of 92 amino acids, starts with an alanine residue, which is conserved in all fish sequences except in salmon (Salmo salar) and trout (Oncorhynchus mykiss), and contains few conserved amino acids (11\% identity between fish 
species). The $\beta-2$ domain is 94 amino acids long, starts with a valine residue conserved in all

285 sequences except in Japanese flounder (Paralichthys olivaceus), red sea bream (Pagrus major) and cichlid (Cyphotilapia frontosa), shows high identity (35\%) in the C-proximal region and ends with a conserved tryptophan residue. The connecting peptide consists of 10 amino acids and the transmembrane domain, that contains 22 residues, and has the highest identity percentage (55\%). The cytoplasmic tail varies in length in the different species and starts with a conserved tyrosine residue in fish species. The cytoplasmic region contains 13 residues in the Dila-DAB sequences.

The cysteine residues present in the $\beta-1$ and $\beta-2$ domains are well conserved in all sequences except in the turbot sequence that lacks the cysteine at position 94 of the Dila-DAB sequences. These residues, presumably forming two disulfide intra-chain bonds, are consistent with previous findings in other species [56-57]. No potential O- or N-glycosylation sites were found in the DilaDAB sequences, in contrast to one present in the red sea bream [11], in the catfish [58] and in rainbow trout [59-60].

Phylogenetic analysis (Fig. 2) conducted using amino acid sequences showed that all fish sequences are in the same cluster and that the six Dila-DAB sequences are in two different groups: one with sequences Dila-DAB*0101, *0201 and *0301 and the other with sequences DilaDAB*0401, *0501,*0601. The first group of sea bass sequences also contains the striped bass Mosa-DAB sequence. The mammalian and avian sequences are in a different cluster with respect to the fish one.

\subsection{Basal MHC class II $\beta$ cha in expression}

The expression analys is of IL-10 in organs and tissues of unstimulated sea bass is shown in

Figure 3. Real-time PCR products were loaded on agarose gels to exclude the formation of non-specific amplicons and, to take into consideration the individual genetic variability, five

different fishes were sampled. MHC class II $\beta$ chain levels were expressed as a ratio relative to $\beta$-actin levels in the same samples after real-time PCR analysis using the tissue with the lowest 
followed by gut and thymus. Lower IL-10 mRNA levels were observed in spleen, PBL, and

\section{1 liver; brain and HK showed the lowest expression levels.}

\subsection{In vitro sea bass MHC class II $\beta$ chain expression after stimulation}

313 To investigate the differential "in vitro" sea bass MHC class II $\beta$ chain expression after 314 stimulation with LPS at 4 and 24 hours and with various rIL- $1 \beta$ concentrations, we used RNA 315 extracted from head kidney leucocytes. Total RNA from 5 different fishes was collected and real316 time PCR primers were selected in the conserved region of all Dila-DAB sequences. After 317 amplification and real-time analysis, PCR products for both MHC class II $\beta$ and $\beta$-actin were 318 loaded on agarose gels to exclude the formation of non-specific amplicons. Dila-DAB mRNA levels were compared to the housekeeping gene $\beta$-actin levels in the same samples and the values of the quantitative analys is were expressed as a ratio relative to $\beta$-actin.

Stimulation with LPS (Fig. 4A) resulted in very little differences in the MHC class II $\beta$ expression after $4 \mathrm{~h}$ with respect to the control at the same time and the statistical analysis performed showed that it was not significant. After $24 \mathrm{~h}$ the MHC expression has decreased to a large extent and, in this case, the difference was statistically significant. Moreover, IL-1 $\beta$ expression (data not shown) was studied in the same samples to be sure of the LPS stimulation and showed an increase of IL-1 $\beta$ levels, as was expected. dependent reduction of the Dila-DAB expression (Fig. 4B), with the lowest value obtain ed from the sample treated with $100 \mathrm{ng} / \mathrm{ml}$ of rIL-1 . The differences were statistically significant for all the samples, except for the cell culture stimulated with $10 \mathrm{ng}$ of rIL-1 $\beta$ and the cell culture stimulated

331 with $50 \mathrm{ng} / \mathrm{ml}$ of rIL- $1 \beta$ pre-heated at $95{ }^{\circ} \mathrm{C}$ for $20 \mathrm{~min}$. The latter observation is consistent with 332 those reported by Hong et al., (2001) [61]. The Dila-DAB mRNA level in this case was almost 333 equal to the control and significantly different with the sample stimulated with the same dose of 334 rIL-1 $\beta$ but not heated. 


\subsection{Sea bass MHC class II $\beta$ protein modelling}

The Dila-DAB sequences have been analysed with the BLAST program in order to find similar sequences in databases and to perform the structural predictions. The crystallographic structures of mouse MHC I-AK $\beta$ chain complexed with D10 T-cell antigen receptor (PDB code: 1D9K) and human CD4 (PDB code: 1JL4) were selected as template models and the mouse sequence showed the maximum identity percentage (34\%) with the Dila-DAB*0101 sequence (data not shown). This low level of sequence identity required an accurate procedure to build a $3 D$ model of the protein by comparative modeling, in agreement with rules recently reviewed [45], as already applied in previous papers $[40-44]$.

We aligned the Dila-DAB*0101 and mouse MHC sequences using the CLUSTALW program and we performed a few manual adjustments in order to remove gaps within $\alpha$-helices or $\beta$-strands (Figure 5). Starting from this alignment two sets of ten structural models were created, in two distinct sessions, for the Dila-DAB 17-206 region using the templates above indicated. We selected the best model created in each session, i.e. Model- ${ }^{\mathrm{D} 9 \mathrm{~K}}$ and Model- ${ }^{1 \mathrm{JL} 4}$ by evaluating the stereo chemical quality of the models with the PROCHECK package [50] and a scoring function with ProsaII program [51]. The models have been deposited in the Protein Data Bank and accepted with the PDB codes $2 \mathrm{H} 37$ and $2 \mathrm{H} 38$, respectively.

Figure 6 shows the two Dila-DAB homology models with their secondary structure elements. These models have a classical organization in two distinct domains in agreement with the structural classification reported by CATH database [53] for the model structures of mouse MHC class II $\beta$ chain. The N-terminal domains are classified as "alpha-beta" and consist of an alpha helical region and a beta sheet of four strands in antiparallel orientation. The C-terminal domains have a "mainly beta" fold and are characterized by an immuno globulin-like beta-sandwich made of two antiparallel sheets, each consisting of three main strands and few shorter strands, organized in greek-keys motifs. In both models of Dila-DAB four cysteine residues are located in the same positions of the mouse structures and they may form an S-S bond (30-95) in the N-terminal domains, and another S- 
S bond (133-189) in the C-terminal domains between the two sheets of the sandwich architecture, as

362 described in mammals [56-57].

363 The two Dila-DAB models were compared by structural superimposition, RMSD evaluation and 364 secondary structures (Figure 5) to evidence structural changes due to the binding with different 365 ligands (in one case T-cell receptor and in another CD4). The presence of gaps in the alignment 366 made it difficult to perform a complete structural comparison of Dila-DAB models with the 367 template structures. Superimposition of structurally conserved regions of Dila-DAB Model- ${ }^{1 \mathrm{JL} 4}$ and 368 Model- ${ }^{1 \mathrm{D} 9 \mathrm{~K}}$ with their respective templates gave RMSD values of 1 Angstrom and 0.96 Angstrom, 369 respectively. In contrast, an RMSD value of 1.22 Angstrom was obtained by superimposition of the 370 two Dila-DAB models, i.e. Model- ${ }^{1 \mathrm{D} 9 \mathrm{~K}}$ and Model- ${ }^{1 \mathrm{LL} 4}$, indicating that these two conformations 371 present some structural differences.

372 The comparison of secondary structures, assigned by DSSP program in all four models, shows 373 that the alpha helices and the beta-strands are quite conserved in the mouse and Dila-DAB models, 374 although some differences are noted. The short $3_{10}$ helix (GTQ) observed in both crystallographic 375 mouse structures is not present in the two Dila-DAB models. In Dila-DAB Model- ${ }^{1 \mathrm{JL} 4}$ an alpha helix $376\left(\right.$ Tyr $^{103}$-Lys $\left.{ }^{110}\right)$ is observed where in mouse MHC I- ${ }^{\mathrm{K}}$ complexed with human CD4 (PDB code: 377 1JL4) a short $3_{10}$ helix (SLR) is present. By comparing the two Dila-DAB models, we note that 378 Model- ${ }^{1 \mathrm{D} 9 \mathrm{~K}}$ has a lower content of beta-strand in the C-terminal domain, where the strands include 379 fewer amino acids and are often broken in two shorter strands. In particular, two short beta-strands, 380 spanning residues $\mathrm{Tyr}^{171}-\mathrm{Ile}^{173}$ and $\mathrm{His}^{176}-\mathrm{Tyr}^{179}$, are present in Model- ${ }^{1 \mathrm{D} 9 \mathrm{~K}}$, while only one long 381 beta-strand $\left(\mathrm{Tyr}^{171}-\mathrm{Tyr}^{179}\right)$ is present in Model ${ }^{1 \mathrm{JL} 4}$. Moreover, Model- ${ }^{1 \mathrm{JL} 4}$ shows one more short 382 beta strand $\left(\mathrm{Val}^{158}-\mathrm{Ser}^{160}\right)$, similar to its template.

383 Finally, we analyzed the mouse structures to identify the regions involved in the interactions 384 with peptides, T-cell antigen receptor and CD4, by means of solvent accessibility and protein385 protein interaction analyses (data not shown). By homology considerations, the aligned regions in 386 the Dila-DAB sequence can be hypothesized to be similarly involved in ligand bind ing. 
396

397

398

399

400

401

402

403

404

405

406

407

408

409

410

411

412

413

414

415

416

417

418

419

420

421

422

423

424

425

426

427

428

429

430

431

432

433

434

\section{DISCUSSION}


The MHC class I and class II molecules are involved in the presentation of antigens to the adaptive immune system. High polymorphism in MHC molecules has been observed in vertebrates and growing evidence suggests that MHC variants influence many important biological traits, including immune recognition, susceptibility to infectious and autoimmune diseases, mating preferences and pregnancy outcome [62]. For these reasons MHC genes are among the best candidates for studies of mechanisms and significance of molecular adaptation in vertebrates. bass (Dicentrarchus labrax). Six different sequences, named Dila-DAB, were obtained. The DilaDAB cDNAs were predicted to code for proteins of 250 amino acids and their size was in accordance with other fish and mammalian MHC class II $\beta$ chain molecules. The alignment of

Figure 1 showed that the $\beta-1$ domains present a variability indicative of a functional peptide binding region and most of the differences between the six Dila-DAB sequences are in this region. On the contrary, the $\beta-2$ domains are quite well conserved, especially in the membrane-proximal region. Proposed sites for the interaction of the MHC class II $\beta$ chain with the MHC class II $\alpha$ chain in mammals [57-58] involve three amino acid residues: two histidines and a glutamic acid. Two of these residues are conserved in all fish sequences ( $\mathrm{His}^{127}$ and $\mathrm{Glu}^{178}$ in the Dila-DAB sequences), 451 while the second histidine residue is substituted in the majority of fish molecules by a proline 452 (Pro ${ }^{128}$ in the Dila-DAB sequences). Putative sites important for human MHC class II $\beta$ chain 453 interaction with CD4 co-receptor are three residues: a valine, a threonine and a serine [57], and 454 these residues are conserved in all fish sequences $\left(\mathrm{Val}^{158}, \mathrm{Thr}^{159}, \mathrm{Ser}^{160}\right.$ in the Dila-DAB 455 sequences). The transmembrane domain is highly conserved and has multiple hydrophobic residues 456 that are interspersed with uncharged glycines at position 219, 222, 226 and 233 in the Dila-DAB 457 sequences as seen in the sequences from other species [63].

458 Phylogenetic analysis, generated using amino acid sequences, showed a close relationship 459 between the Dila-DAB and Mosa-DAB sequences (Fig. 2) providing evidence for trans-species 
evolution of the class II sequences. The bootstrapped tree was divided into two different branches with one containing all fish sequences and the other with mammalian and avian ones.

Moreover, our data suggest that MHC class II $\beta$ is present in a ubiquitous manner in nonstimulated tissues and organs, although with different expression levels. The highest expression was found in gills that in fish are constantly exposed to a plethora of water born antigens. Moreover, some pathogens use the gills as a portal of entry into the host [64] while others use this organ as the site of infection [65]. Therefore, the ability to mount strong local immune reactions to pathogens is fundamental to avoid disease as already observed in Atlantic salmon [66]. It should be noted that expression of MHC class II $\beta$ is notably elevated in the gut that is a mucosal tissue particularly $\mathrm{rich}$ in T-cels in sea bass [67].

The "in vitro" MHC class II $\beta$ chain expression was studied using head kidney leukocytes, because this tissue in the red sea bream, a species related to sea bass, showed the highest basal MHC $\beta$ chain expression [11]. The selected stimulants were LPS, to simulate a pathogen infection, and the sea bass rIL-1 $\beta$. This cytokine was chosen as it should promote phagocytosis of foreign particles, which are subsequently presented to T-cells in conjunction with MHC molecules [68]. LPS stimulation resulted in a down-regulation of Dila-DAB, which was statistically significant after $24 \mathrm{~h}$ and in an increase of IL-1 $\beta$ gene expression (data not shown), that was used to test the efficacy of the activation. This is in accordance with the results found in a macrophage-like cell line (SHK-1) derived from Atlantic salmon [69-70]. A similar down-regulation of MHC class II was also obtained after challenge with Vibrio anguillarum in red sea bream [11] and of MHC class I after infection with hematopoietic necrosis virus (IHNV) in rainbow trout [71]. Recombinant sea bass IL- $1 \beta$ produced a dose-dependent down-regulation in the concentrations used and this has also been observed in various human cell types [72]. It has been postulated that IL-1 $\beta$ plays a role in regulating immunoreactivity by inhibiting transcription of the CIITA gene, thereby reducing class II MHC expression in mammal cell lines [73]. The stimulation has also been performed with 
heat inactivated rIL-1 $\beta$ to confirm that the observed down-regulation was due to the cytokine stimulation. MHC down-regulation could be very likely linked to the already reported mechanisms for the control of inflammation responses in mammals that, uncontrolled, may have dange rous effects. During early inflammation, various cytokines are produced and they down-regulate the expression of inflammation-related molecules [74]. More experiments and tools will be required to demonstrate that something similar happens in fish.

The percentage identity between the $\mathrm{N}$-terminal region of the Dila-DAB*0101 sequence (amino acids 17-206) and mouse MHC sequence, for which crystallographic structures complexed with D10 T-cell antigen receptor and human CD4 are available, gave us the opportunity to apply homology modelling techniques and study the predicted 3D Dila-DAB structures. The two obtained models (Fig. 5) differ mainly in the ligand binding regions. In Model- ${ }^{1 \mathrm{LL} 4}$, we observed that both the antigen peptide binding site (1360 vs 1309 Angstrom $^{2}$ ) and the interaction surface with CD4 ( 775 vs 742 Angstrom $^{2}$ ) were larger than in the Model- ${ }^{1 \mathrm{D} 9 \mathrm{~K}}$. On the contrary, the interaction surface with the T-cell antigen receptor was larger in Model- $^{1 \mathrm{D} 9 \mathrm{~K}}$ (1144 vs 1095 Angstrom $^{2}$ ). The fact that each model presents a larger interaction surface for the respective ligand confirms the reliability of the prediction. The experimental use of synthetic peptides designed on the basis of the amino acids present on the interaction surfaces with the two different ligands should block the non-covalent bond and will be useful to confirm the structural prediction and for functional investigations.

In conclusion, the availability of these Dila-DAB sequences will add new insight into the MHC variability in vertebrates, that is linked to parasite resistance, and will give the possibility to analyse the sea bass MHC class II expression levels after vaccination and immuno-stimulation protocos.

[1] Auffray C, Strominger JL. Molecular genetics of the human major histocompatibility complex. Adv Hum Genet 1986; 15:197-247. 
511 [2] Lanzavecchia A. Receptor mediated antigen uptake and its effect on antigen presentation to 512 class II-restricted T lymphocytes. Ann Rev Immunol 1990; 8:773-93.

513 [3] Konig R, Huang L-Y, Germain RN. MHC class II interaction with CD4 mediated by a region $514 \quad$ analogous to the MHC class binding site. Nature 1992;356:796-98.

515 [4] Brodsky FM, Guagliardi LE. The cell biology of antigen processing and presentation. Ann Rev $516 \quad$ Immunol 1991; 9:707-44.

517 [5] Fremont DH, Monnaie D, Nelson CA, Hendrickson WA, Unanue ER. Crystal structure of I-A 518 in complex with a dominant epitope of lysozyme. Immunity 1998; 8:305-17.

519 [6] Scott CA, Peterson PA, Teyton L, Wilson IA. Crystal structures of two I-A ${ }^{\mathrm{d}}$-peptide complexes 520 reveal that high affinity can be achieved without large anchor residues. Immunity 1998; 8:31952129.

522 [7] McFarland BJ, Katz JF, Sant AJ, Beeson C. Energetics and cooperativity of the hydrogen 523 bonding and anchor interactions that bind peptides to MHC class II protein. J Mol Biol 2005; $524 \quad 350: 170-83$.

525 [8] Stet RJM, Kruiswijk CP, Dixon B. Major his tocompatibility lineages and immune gene function 526 in teleost fish es: the road not taken. Crit Rev Immunol 2003; $23: 441-71$.

527 [9] Sato A, Figueroa F, Murray BW, Malaga-Trillo E, Zaleska-Rutczynska Z, Sultmann H et al. 528 Nonlinkage of major histocompatibility complex class I and class II loci in bony fishes. 529 Immunogenetics 2000; 51:108-16.

530 [10] Walker RB, McConnell TJ, Walker RA. Variability in a MHC Mosa class II beta chain$531 \quad$ encoding gene in striped bass (Morone saxatilis). Dev Comp Immunol 1994; 18:325-42.

532 [11] Chen S-L, Zhang Y-X, Xu M-Y, Ji X-S, Yu G-C, Dong C-F. Molecular polymorphism and 533 expression analysis of MHC class II $B$ gene from red sea bream (Chrysophrys major). Dev $534 \quad$ Comp Immunol 2006; 30: 407-18.

535 [12] Figueroa F, Mayer WE, Sultmann H, O’hUigin C, Tichy H, Satta Y et al. MHC class II B gene 536 evolution in East African cichlid fishes. Immunogenetics 2000; 51:556-75. 
[13] Miller KM, Withler RE. Sequence analysis of a polymorphic $M H C$ class II gene in Pacific salmon. Immunogenetics 1996; 43:337-51.

[14] Ristow SS, Grabowski LD, Thompson SM, Warr GW, Kaattari SL, de Avila JM, Thorgaard GH. Coding sequences of the MHC II $\beta$ chain of homozygous rainbow trout (Oncorhynchus mykiss). Dev Comp Immunol 1999; 23:51-60.

[15] Stet RJM, de Vries B, Mudde K, Hermsen T, van Heerwaarden J, Shump BP, Grimholt U. Unique haplotypes of co-segregating major histocompatibility class II A and class II B alleles in Atlantic salmon (Salmo salar) give rise to diverse class II genotypes. Immunogenetics $2002 ; 54: 320-31$

[16] Sultmann H, Mayer WE, Figueroa F, O’hUigin C, Klein J. Zebrafish MHC class II $\alpha$ chainencoding genes: polymorphism, expression, and function. Immunogenetics 1993; 38: 408-20.

[17] Dixon B, Nagelkerke LAJ, Sibbing FA, Egberts E, Stet RJM. Evolution of $M H C$ class II $\beta$ chain-encoding genes in the Lake Tana barbell species flock (Barbus intermedius complex). Immunogenetics 1996; 44: 419-31.

[18] Graser R, O’hUigin C, Vincek V, Meyer A, Klein J. Trans-species polymorphism of class II MHC loci in danio fishes. Immunogenetics 1996; 44:36-48.

[19] van Erp SHM, Egberts E, Stet RJM. Characterization of major histocompatibility complex class II A and B genes in a gynogenetic carp clone. Immunogenetics 1996; 44:192-202.

[20] Stet RJM, Kruiswijk CP, Saeij JPJ, Wiegertjes GF. Major histo compatibility genes in cyprinid fishes: theory and practice. Immunological Reviews 1998; 166:301-16.

[21] Grimholt U, Larsen S, Nordmo R, Midtlyng P, Kjoeglum S, Storset A, et al. MHC polymorphism and disease resistance in Atlantic salmon (Salmo salar); facing pathogens with single expressed major histocompatibility class I and class II loci. Immunogenetics 2003; 55:210-19. 
[22] Kurt J, Kalbe M, Aeschlimann PB, Haberli MA, Wegner KM, Reusch TB, Milinski M. Major histocompatibility complex diversity influences parasite resistance and innate immunity in sticklebacks. Proc Biol Sci 2004; 271:197-204.

[23] Koppang EO, Lundin M, Press McL, Ronningen K, Lie O. Differing levels of Mhc class II $\beta$ chain expression in a range of tissues from vaccinated and non-vaccinated Atlantic salmon (Salmo salar L.). Fish Shellfish Immunol 1998; 8:183-96.

[24] Park KC, Osborne JA, Tsoi SC, Brown LL, Johnson SC. Expressed sequence tags analysis of Atlantic halibut (Hippoglossus hippoglossus) liver, kidney and spleen tissues following vaccination against Vibrio anguillarum and Aeromonas salmonicida. Fish Shellfish Immunol $2005 ; 18: 393-415$.

[25] Tafalla C, Coll J, Secombes CJ. Expression of genes related to the early immune response in rainbow trout (Oncorhynchus mykiss) after viral haemorrhagic septicemia virus (VHSV) infection. Dev Comp Immunol 2005; 29:615-26.

[26] Morrison RN, Koppang EO, Hordvik I, Nowak BF. MHC class $\mathrm{II}^{(+)}$cells in the gills of Atlantic salmon (Salmo salar L.) affected by amoebic gill disease. Vet Immunol Immunopathol 2006; 109:297-303.

[27] Wegner KM, Kalbe M, Rauch G, Kurtz J, Schaschl H, Reusch TB. Genetic variation in MHC class II expression and interactions with MHC sequence polymorphism in three-spined sticklebacks. Mol Ecol 2006; 15: 1153-64.

[28] Hill AV, Allsopp CEM, Kwiatkowski D, Anstey NM, Twumasi P, Rowe PA, et al. Common West African HLA antigens are associated with protection from severe malaria. Nature 1991; 352:595-600.

[29] Hofmann A, Plachy J, Hunt L, Kaufman J, Hala K. v-src oncogene-specific carboxy-terminal peptide is immunoprotective against Rous sarcoma growth in chickens with MHC class I allele B-F 12. Vaccine 2003; 21:4694-9. 
586 [30] Venkatesh B, Ning Y, Brenner S. Late changes in spliceosomal introns define clades in $587 \quad$ vertebrate evolution. Proc Natl Acad Sci USA 1999; 96: 10267-71.

588 [31] Scapigliati G, Buonocore F, Bird S, Zou J, Pelegrin P, Falasca C, Prugnoli D, Secombes CJ. 589 Phylogeny of cytokines: molecular cloning and expression analysis of sea bass Dicentrarchus labrax interleukin-1 beta. Fish Shellfish Immunol 2001; 11:711-26.

591 [32] Pearson WR, Lipman DJ. Improved tools for biological sequence comparison. Proc Natl Acad 592 Sci USA 1988; $85: 2444-8$.

593 594

[33] Altschul SF, Gish W, Miller W, Myers E, Lipman DJ. Best local alignment search tool. J Mol Biol 1990; $215: 403-10$.

[34] Kumar S, Tamura K, Nei M (2004). MEGA3: Integrated Software for Molecular Evolutionary Genetics Analysis and Sequence Alignment. Briefings in Bioinfiormatics 2004; 5: 150-63.

[35] Nielsen H, Engelbrecht J, Brunak S, von Heijne G. Identification of prokaryotic and eukaryotic signal peptides and prediction of their cleavage sites. Protein Eng 1997; 10:1-6.

[36] Julenius K, Molgaard A, Gupta R, Brunak S. Prediction, conservation analysis and structural characterization of mammalian mucin-type O-glycosylation sites. Glycobiology 2005; 15:15364.

[37] Brudno M, Chapman M, Gottgens B, Batzoglou S, Morgenstern B. Fast and sensitive multiple alignment of large genomic sequences. BMC Bioinformatics 2003; 4:66-77.

[38] Buonocore F, Mazzini M, Forlenza M, Randelli E, Secombes CJ, Zou J, Scapigliati G. Expression in Escherichia coli and purification of sea bass (Dicentrarchus labrax) interleukin-1 $\beta$, a possible immuno-adjuvant in aquaculture. Marine Biotech. 2004; 6:53-9.

[39] Buonocore F, Forlenza M, Randelli E, Benedetti S, Bossù P, Meloni S, et al. Biological activity of sea bass (Dicentrarchus labrax) recombinant interleukin-1 $\beta$. Marine Biotech. 2005; 7:609-17. 
610 [40] Facchiano AM, Stiuso P, Chiusano ML, Caraglia M, Giuberti G, Marra M, et al. Homology 611 modelling of the human eukaryotic initiation factor 5A (eIF-5A). Protein Engineering 2001; $612 \quad 14: 881-90$.

613 [41] Marabotti A, D’Auria S, Rossi M, Facchiano AM. Theoretical model of the three-dimensional 614 structure of a sugar binding protein from Pyrococcus horikoshii: structural analysis and sugar 615 binding simulations. Biochem J 2004; 280:677-84.

616 [42] Scapigliati G, Costantini S, Colonna G, Facchiano A, Buonocore F, Bossù P, et al. Modelling 617 of fish interleukin 1 and its receptor. Dev Comp Immunol 2004; 28:429-41.

618 [43] Costantini S, Colonna G, Rossi M, Facchiano AM. Modelling of HLA-DQ2 and simulations of 619 its interaction with gluten peptides to explain molecular recognition in celiac disease. J $620 \quad$ Molecular Graphics and Modelling 2005;23:419-31.

621 [44] Buonocore F, Randelli E, Bird S, Secombes CJ, Costantini S, Facchiano A, et al. The 622 CD8alpha from sea bass (Dicentrarchus labrax L.): cloning, expression and 3D modelling. Fish Shellfish Immunol 2006; 20:637-46.

[45] Wallner B, Elofsson A. All are not equal: a benchmark of different homology modelling programs. Protein Science 2005; 14:1315-27.

[46] Reinherz EL, Tan K, Tang L, Kern P, Liu J, Xiong Y, et al. The crystal structure of a T cell receptor in complex with peptide and MHC class II. Science 1999; 286:1913-21.

[47] Wang JH, Meijers R, Xiong Y, Liu JH, Sakihama T, Zhang R, et al. Crystal structure of the human CD4 N-terminal two-domain fragment complexed to a class II MHC molecule. Proc Natl Acad Sci USA 2001; 98:10799-804.

631 [48] Thompson JD, Higgins DG, Gibson TJ. Clustal W: Improving the sensitivity of progressive multiple sequence alignment through sequence weighting, position-specific gap penalties and weight matrix choice. Nucl Acids Res 1994; 22:4673-80.

634 [49] Sali A, Blundell TL. Comparative protein modelling by satisfaction of spatial restraints. J Mol 635 Biol 1993 ;234:779-815. 
636 [50] Laskowski RA, MacArthur MW, Moss DS, Thornton JM PROCHECK: a program to check the 637 stereochemical quality of protein structures. J Appl Cryst 1993;26:283-91.

638 [51] Sippl MJ. Recognition of errors in three-dimensional structures of proteins. Proteins 1993; $639 \quad 17: 355-62$.

640 [52] Kabsch W, Sander C. Dictionary of protein secondary structure: pattern recognition of 641 hydrogen-bonded and geometrical features. Biopolymers 1983;22: 2577-637.

642 [53] Orengo CA, Michie AD, Jones S, Jones DT, Swindells MB, Thornton JM. CATH--a hierarchic $643 \quad$ classification of protein domain structures. Structure 1997;5:1093-108.

644 [54] Jones S, Thornton JM. Principles of protein-protein interactions derived from structural $645 \quad$ studies. Proc Natl Acad Sci 1996;93:13-20.

646 [55] Hubbard SJ, Campbell SF, Thornton JM. Molecular recognition. Conformational analysis of 647 limited proteolytic sites and serine proteinase protein inhibitors. J Mol Biol 1991;220:507-30.

648

649

650

652

653

654

655

656 657

[56] Klein J. Natural history of the major histocompatibility complex. New York: John Wiley; 1986.

[57] Brown JH, Jardetzky TS, Gorga JC, Stern LJ, Urban RG, Strominger JL, Wiley DC. Threedimensional structure of the human class II histocompatibility antigen HLA-DR1. Nature $1993 ; 364: 33-9$.

[58] Godwin UB, Antao A, Wilson MR, Chinchar G, Miller NW, Clem W, McConnell TJ. MHC class II $B$ genes in the channel catfish (Ictalurus punctatus). Dev Comp Immunol 1997;21:1323.

[59] van Lierop M-J C, Knight J, Secombes CJ, Hermsen TT, Groeneveld A, Stet JM. Production and characterisation of an antiserum raised against recombinant rainbow trout (Oncorhynchus mykiss) MHC class II beta-chain (MhcOnmy-DAB). Fish Shellfish Immunol 1998;8:231-43.

[60] Nath S, Kales S, Fujiki K, Dixon B. Major histocompatibility class II genes in ra inbow trout (Oncorhynchus mykiss) exhibit temperature dependent downregulation. Immunogenetics 2006; 58: 443-53. 
662 [61] Hong S, Zou J, Crampe M, Peddie S, Scapigliati G, Bols N, et al. The production and 663 bioactivity of rainbow trout (Oncorhynchus mykiss) recombinant IL-1ß. Vet Immunol $664 \quad$ Immunopatol 2001;81:1-14.

665 [62] Sommer S. The importance of immune gene variability (MHC) in evolutionary ecology and $666 \quad$ conservation. Front Zool 2005; 2:16.

667 [63] Cosson P, Bonifacino JS. Role of the transmembrane domain interactions in the assembly of $668 \quad$ class II MHC molecules. Science 1992; 258:659-62.

669 [64] Morris DJ, Ada ms A, Richards RH. In situ hybridisation identifies the gill as a portal of 670 entry for PKK (Phylum Myxozoa), the causative agent of proliferative kidney disease in salmonids. Parasitol. Res. 2000; 86: 950-6.

[65] Ramsay E, Falk K, Mikalsen AB, Teig A. Xenoma formation during microsporidial gill disease of salmonids caused by Loma salmonae is affected by host species (Oncorhynchus tshawytscha, O. kisutch, O. mykiss) but not by salinity. Dis Aquat Org 2002 ; 48: 125-31.

[66] Morris on RN, Koppang EO, Hordvik I., Nowak BF. MHC class II+ cells in the gills of the Atalntic salmon (Salmo salar L.) affected by amoebic gill disease. Vet Immunol

[67] Abelli L., Picchietti S., Romano N., Mastrolia L., Scapigliati G. 1997. 679 Immunohistochemistry of gut-associated lymphoid tissue of the sea bass Dicentrarchus labrax (L.). Fish Shellfish Immunol. 1997; 7: 235-46.

[68] Dinarello CA. The interleukin-1 family: 10 years of discovery. Fed Am Soc Exp Biol 1994; 8:1314-25.

[69] Koppang EO, Dannevig BH, Lie O, Ronningen K, Press CM. Expression of the MHC class I 685 and II mRNA in a macrophage-like cell line (SHK-1) derived from Atlantic salmon, Salmo salar, head kidney. Fish Shellfish Immunol 1999; 9:473-89. 
[70] Fast MD, Ross NW, Johnson SC. Prostaglandin $E_{2}$ modulation of gene expression in an Atlantic salmon (Salmo salar) macrophage-like cell line (SHK-1). Dev Comp Immunol 2005; 29:951-63.

[71] Hansen JD, La Patra S. Induction of the rainbow trout MHC class I pathway during acute IHNV infection. Immunogenetics 2002;54:654-61.

[72] Watanabe Y, Lee S, Allison AC. Control of the expression of a class II major histocompatibility gene (HLA-DR) in various human cell types: down-regulation by IL-1 but not IL-6, prostaglandin $E_{2}$, or glucocorticoids. Scand J Immunol 1990;32:601-9.

[73] Rohn W, Tang LP, Dong W, Benveniste ET. IL-1 $\beta$ inhibits IFN- $\gamma$-induced class II MHC expression by suppressing transcription of the class II transactivator gene. J Immunol 1999; $162: 886-96$.

[74] Coronel A, Boyer A, Franssen JD, Romet-Lemonne JL, Fridman WH, Teillaud JL. Cytokine production and T-cell activation by macrophage-dendritic cells generated for the rapeutic use. Br J Haematol 2001; 114: 671-80.

\section{ACKNOWLEDGEMENTS}

This work was supported by the European Commission within the project IMAQUANIM (EC contract number FOOD-CT-2005-007103).

\section{FIGURE LEGENDS}

Fig. 1. Alignment of the predicted sea bass Dila-DAB amino acid sequences with other known MHC class II $\beta$ chain molecules. Regions corresponding to the putative signal peptide, $\beta$-1 domain, $\beta$-2 domain, connecting peptide, transmembrane region and cytoplasmic tail are shown above the sequences. Conserved cysteine residues are evidenced in bold, 
conserved amino acid residues are indicated with an asterisk, while amino acid residues present at the starting point of the different regions considering the human crystal structure are in bold and underlined. Accession numbers: Dila-DAB *0101 (Dicentrarchus labrax) AM1 13466; Dila-DAB *0201 (Dicentrarchus labrax) AM113467; Dila-DAB *0301 (Dicentrarchus labrax) AM113468; Dila-DAB *0401 (Dicentrarchus labrax) AM1 13469; Dila-DAB *0501 (Dicentrarchus labrax) AM113470; Dila-DAB *0601 (Dicentrarchus labrax) AM113471; Japanese flounder (Paralichthys olivaceus) AY848955; turbot (Scophthalmus maximus) DQ001730; Atlantic salmon (Salmo salar) X70167; red sea bream (Pagrus major) AY190711; striped sea bass (Morone saxatilis) L33967; rainbow trout (Oncorhynchus mykiss) AF115529; catfish (Ictalurus punctatus) U77597; humphead cichlid (Cyphotilapia frontosa) L13231; human (Homo sapiens) CAA47028; mouse (Mus musculus) AAC05286); chicken (Gallus gallus) NP_001038144).

Fig. 2. Phylogenetic tree showing the relationship between Dila-DAB sequences with other known MHC class II $\beta$ molecules. The tree was constructed by the "neighbour-joining" method and was bootstrapped 10000 times. 0.1 indicates the genetic distance.

Fig. 3. MHC class II $\beta$ chain basal expression in different tissues [spleen, periphe ral blood leukocytes (PBL), brain, liver, gut, thymus, head kidney (HK), gills]. MHC class II $\beta$ mRNA levels were expressed as a ratio relative to $\beta$-actin levels in the same samples after real-time PCR analysis using the tissue with the lowest expression as calibrator.

Fig. 4. MHC class II $\beta$ expression in different stimulating conditions. (A): MHC mRNA levels expressed as a ratio relative to $\beta$-actin levels in the same samples after real-time PCR analysis of the head kidney leukocytes stimulated with no LPS (control) and with LPS for 4 and $24 \mathrm{~h}$. (B): MHC mRNA levels expressed as a ratio relative to $\beta$-actin levels in 
the same samples after real-time PCR analysis of the head kidney leukocytes stimulated with various rIL- $1 \beta$ concentrations.

Data were expressed as the mean $\pm \mathrm{SE}, *$ indicates $\mathrm{p}<0.05$ and therefore significantly lower than the respective control.

Fig. 5. Primary and secondary structures of mouse and Dila-DAB*0101 chains, aligned as for the modelling procedure. Stars $(*)$ indicate identical amino acids. The interaction residues of mouse MHC-II with the antigen peptide, the D10 T-cell antigen receptors alpha and beta chains (N-terminal region) and human CD4 (C-terminal region) are reported in bold. Helices and beta strands are marked with continuous and dashed line boxes, respectiv ely. template the structure of mouse $\mathrm{MHC} I-\mathrm{A}^{\mathrm{K}}$ chain $\beta$ complexed with human $\mathrm{CD} 4$, i.e. Models- $^{1 \mathrm{JL} 4}$ (a) and with D10 T-cell antigen receptor, i.e. Models- ${ }^{1 \mathrm{D} 9 \mathrm{~K}}$ (b). Backbone ribbon and the secondary structure topology are shown: yellow arrows represent beta strands, red cylinders represent alpha helices. Amino and carboxy terminal ends are indicated. Green and yellow sticks indicate the possible presence of two Cys-Cys bonds in each model. 